\title{
INFLUENCE OF PLYOMETRIC TRAINING ON BREATH HOLDING TIME OF VOLLEYBALL PLAYERS
}

\author{
E. Jenzer Vino ${ }^{1}$ and Dr. P. Kumaresan ${ }^{2}$ \\ ${ }^{I}$ C. S. I. V. V. H. S. S, Irenipuram, Kanyakumari (Dt) TamilNadu, India. \\ ${ }^{2}$ Department of Physical Education, M. D. T. Hindu College, Tirunelveli, TamilNadu, India.
}

\begin{abstract}
The purpose of this study was to find out the influence of plyometric training on breath holding time of volleyball players. Only thirty men volleyball players were selected as subjects at random from the Scott Christian College, Nagercoil, Tamilnadu, India. The selected subjects were divided into two groups of fifteen each. Group I underwent plyometric training, Group II acted as control group who did not participate in any other training other than their regular routine. The age of the subjects ranged from 17 to 22 years. During the training period the experimental groups underwent their respective training programme in addition to their regular programme of the course of study. The duration of training session in the twelve weeks was between 45 to 75 minutes approximately, including warming up and cool down. The data collected from the two groups before and after the experimental period were analyzed by using the analysis of covariance (ANCOVA) and it revealed that the statistically significant differences were found among experimental and control groups. Plyometric training group significantly improved the physiological variable breath holding time of volleyball players.
\end{abstract}

Key Words: Plyometric Training, Breath holding time.

\section{INTRODUCTION}

Volleyball is a game played indoors and outdoors by two teams with 6 members each. They seek to score points in the course of hitting the ball back and forth across a net. "The Term plyometric can be used to include both depth jumping, hopping and bounding drills. They are very dynamic movements which use gravitational force of the body and the contractibility and elasticity of muscle tissue to increase the force or stress on related muscles.

Plyometric exercises are used to improve maximum strength and speed of movements, which results is to increase of explosive power. Dynamic is nature, these exercises will satisfy the basic training principles of specificity practice with movements similar to nature and speed to the skills or events for which one is trained. Because it stimulates quick movements better than most weight lifting, this training method should be supplemented to a weight-training programme.

\section{METHODOLOGY}

Only thirty men volleyball players were selected as subjects at random from the Scott Christian College, Nagercoil, Tamilnadu, India. The selected subjects were divided into two groups of fifteen each. Group I underwent plyometric training for three alternate days in a week for a period of twelve weeks. Group II acted as control group who did not participate in any other training other than their regular routine. The age of the subjects ranged from 17 to 22 years. The duration of training session in the twelve weeks was between 45 to 75 minutes approximately, including warming up and cool down. Group II acted as control. The purpose was to measure the ability of the subject hold the breath for longer time. The subject stands at ease and inhaled deeply after which he held his breath for length of time possible to him. The index finger of the respondent serves as an indicator to the investigator to know the start and end of the recording time the thumb and middle finger were used to hold the nose to avoid letting the air through the nostrils. The subjects were requested not to let the air out by opening the mouth while recording the breath holding time. The time of holding the breath till one subject let the air out was clocked by using the stopwatch to the nearest one tenth of a second as breath- holding time. The pre and post test were taken before and after the training programme. Analysis of covariance was used to test the level of significance. 


\section{RESULTS}

TABLE I

MEANS, STANDARD DEVIATIONS AND DEPENDENT ' $t$ ' TEST VALUES ON BREATH HOLDING TIME OF EXPERIMENTAL AND CONTROL GROUPS

\begin{tabular}{|c|c|c|c|c|}
\hline \hline \multirow{2}{*}{ Test } & \multicolumn{2}{|l|}{$\begin{array}{l}\text { Plyometric } \\
\text { training }\end{array}$} & \multicolumn{2}{c|}{ Control Group } \\
\cline { 2 - 5 } & Mean & SD & Mean & SD \\
\hline Pre test & 41.87 & 2.70 & 42.60 & 2.67 \\
\hline Post test & 44.93 & 2.58 & 42.47 & 2.77 \\
\hline T-Test & \multicolumn{2}{|c|}{$\mathbf{9 . 2 8}^{*}$} & \multicolumn{2}{c|}{$\mathbf{0 . 2 9}$} \\
\hline
\end{tabular}

*Significant at .05 level. The Table Value required at .05 level with df 14 is 2.14 .

From the table I, the obtained t-test value of plyometric training group are 9.28 which are greater than the tabulated t-value of 2.14 with df 14 at .05 level of confidence. This means that the plyometric training group had effects on participants' Breath holding time. Control group did not shown improvement on participants' Breath holding time.

\section{TABLE II \\ RESULTS OF ANALYSIS OF COVARIANCE ON BREATH HOLDING TIME AMONG EXPERIMENTAL AND CONTROL GROUPS}

\begin{tabular}{|c|c|c|c|c|c|c|}
\hline \multicolumn{4}{|c|}{ Adjusted Post Test Means } & \multirow[b]{2}{*}{ df } & \multirow[b]{2}{*}{$\begin{array}{c}\text { Mean } \\
\text { Squares }\end{array}$} & \multirow[b]{2}{*}{ F-ratio } \\
\hline $\begin{array}{l}\text { Plyometri } \\
\text { c training }\end{array}$ & $\begin{array}{c}\text { Control } \\
\text { Group }\end{array}$ & $\begin{array}{c}\text { Sources } \\
\text { Of } \\
\text { Varianc } \\
\text { e }\end{array}$ & $\begin{array}{l}\text { Sum of } \\
\text { Square }\end{array}$ & & & \\
\hline \multirow[t]{2}{*}{45.41} & \multirow[t]{2}{*}{42.36} & & 698.56 & 3 & 232.85 & \multirow[t]{2}{*}{$78.70^{*}$} \\
\hline & & Within & 162.72 & 55 & 2.96 & \\
\hline
\end{tabular}

*Significant at .05 level. The Table Value required at .05 level with df $3 \& 56$ is 2.77.

The obtained F-ratio value is 78.70, which is higher than the table value 2.77 with df 3 and 56 required for significance at .05 level. Since the value of F-ratio is higher than the table value, it indicates that there was significant difference among the adjusted post-test means plyometric training, control group. To find out significant difference, the Scheffe's post-hoc test was applied and the results are presented in Table 


\section{TABLE III}

\section{SCHEFFE'S TEST FOR THE DIFFERENCES BETWEEN THE ADJUSTED POST TEST PAIRED MEANS OF BREATH HOLDING TIME}

\begin{tabular}{|c|c|c|c|}
\hline \hline \multicolumn{4}{|c|}{ Adjusted Post Test Mean } \\
\hline $\begin{array}{c}\text { Plyometric } \\
\text { training }\end{array}$ & $\begin{array}{c}\text { Control } \\
\text { Group }\end{array}$ & $\begin{array}{c}\text { Mean } \\
\text { Differences }\end{array}$ & $\begin{array}{c}\text { Confidence } \\
\text { Interval }\end{array}$ \\
\hline 45.41 & 42.36 & $\mathbf{3 . 0 4} *$ & $\mathbf{1 . 4 8}$ \\
\hline
\end{tabular}

*Significant at .05 level.

Table 3 shows that the adjusted post test mean differences on Breath holding time between plyometric training and control group are greater than the confidence interval value 1.48 , which shows significant difference at .05 level of confidence.

\section{DISCUSSION AND FINDINGS}

The results of the study indicate that there is a significant difference in on Breath holding time between plyometric training and control group. Plyometric training group is better than control group in improving Breath holding time. The results of the study indicate that plyometric training group improved the Breath holding time when compared to the control group.

\section{CONCLUSION}

The findings of the present study confirmed by the research findings. Plyometric training group significantly improved the physiological variable Breath holding time of volleyball players.

\section{REFERENCES}

[1] Barrow M and Rose Mary Mc Gee, A Practical approach to measurement in Physical Education, (Philadelphia: Lea and Febiger, 1973).

[2] Daniel D. Arnbein, Modern Principles of Athletic Training, (St. Louis: The C.V. Mosby Company, 1963).

[3] Donald K. Mathews, Test and Measurement in Physical Education, (1963).

[4] Henry Cecil Wyld and Eric H. Partridge (ed) Webster Universal Dictionary (Bombay: Tulisha Enterprises, 1970).

[5] Karpovich, "A comparison of physical fitness of children in lowa, USA and Tokyo, Japan”, Research Quarterly, Vol.33 (Dec. 1962).

[6] Perry Johnson and Donald Stelberg, Conditioning (Englewood Cliffs: N.J. Prentice Hall Inc., 1971).

[7] Larson L.A. and Yocorn R.A., Measurement and Evaluation in Physical Education, Health and Recreation (St. Louis: the C.V. Mosby Company, 1957). 